Mr Radosav Nikolić, pukovnik, dipl. inž. Vojna akademija - Odsek logistike,

vanredni profesor

dr Zoran Nikolić, dipl. inž

Institut tehničkih nauka SANU Beograd

\section{POJAVA KAVITACIJE U BRODSKIM DIZEL MOTORIMA}

\author{
UDC: $532.528:[621.436: 623.82]$
}

Rezime:

U radu je obraden proces nastajanja kavitacije, uzroci koji dovode do njene pojave, kao i posledice koje izaziva na materijalima. Razmotren je uticaj kavitacije na delove brodskih dizel motora koji se hlade vodom, kao i kavitacione erozije na površine cilindarskih košljica hlađenih vodom. Težište rada posvećeno je uzrocima nastajanja kavitacije na rashladnim površinama brodskih dizel motora, a posebno uticaju vrste rashladne tečnosti, pritiska i temperature na gubitak mase modela ispitivanih na kavitaciju u jednakim uslovima i na istom uređaju. Posebno je izvršena analiza i upoređenje kavitacionih razaranja od pritiska $i$ temperature rashladne tečnosti.

Ključne reči: brodski dizel motor, kavitacija, košuljica cilindra, rashladna tečnost.

\title{
THE CAVITATION IN MARINE DIESEL ENGINES
}

Summary:

This paper work presents the cavitation arises, causes of its appearing and consequences which it setsup on materials. It represents the influence of cavitation on parts of marine Diesel engines cooled by water, as well as, influence of cavitation erosion on surface of the cylinder liner cooled by water. The focus of this paperwork is the influence of cavitation appearing on cooling surfaces of marine Diesel engines, and specially the influence of cooling fluid type, pressure and temperature on the loss of mass of models examined on cavitation in equal conditions and on the same device. Particularly performed analysis and comparison of cavitation destruction dependent on pressure and temperature of cooling fluid.

Key words: marine Diesel engines, cavitation, cylinder liner, cooling fluid.

\section{Uvod}

Sagorevanjem goriva $\mathrm{u}$ cilindru brodskog dizel motora oslobađa se određena količina toplotne energije koja se pretvara u mehanički rad. Deo te energije prenosi se i na delove motora koji se pri tome zagrevaju, što ima za posledicu povećanje njihove temperature. Da bi se sprečilo nekontrolisano zagrevanje delova motora vrši se hlađenje: spoljnih površina cilindarskih košuljica, cilindarskih glava, klipova, izduvnih ventila, vazduha iza turbokompresora i turbokompresora, dok se ostali delovi hlade indirektno uljem za podmazivanje.

Visokotermički opterećeni savremeni brodski dizel motori hlade se na više načina, a na brodovima najčešće vodom, pri čemu se javljaju određeni problemi zbog oštećenja rashladnih površina. Ova oštećenja posledica su većeg broja faktora, a jedan od njih je uticaj kavitacije. 
Najveći intenzitet oštećenja primećen je na površinama cilindarskih košuljica i blokova motora koje su u dodiru sa rashladnom tečnošću. Posebno su izražena oštećenja nastala kavitacionom erozijom motora lakših konstrukcija. Međutim, kod motora sa većom specifičnom masom ta oštećenja su zanemarljiva. Uzrok većih oštećenja, nastalih kavitacionom erozijom, povezan je sa povećanim oscilacijama tankih cilindarskih košuljica. Erozija cilindarske košuljice umanjuje njenu čvrstoću i ta oštećenja su najčešće trajna.

Povećanjem snage i srednjeg efektivnog pritiska srednjebrzohodnih i sporohodnih brodskih dizel motora primećena su veća oštećenja nastala uticajem kavitacije, kako na cilindarskim košuljicama, tako i na blokovima cilindara motora. Istraživanjem problema kavitacije na određenim tipovima brodskih dizel motora ustanovljeno je da je razaranje cilindarskih košuljica intenzivno, i da se nakon 12000 do 15000 radnih časova dizel motora ove košuljice moraju remontovati ili zameniti. U velikom broju slučajeva razaranja nastala uticajem kavitacije prouzrokuju i pojavu pukotina neposredno ispod prirubnice cilindarske košuljice.

Zbog stalnog povećanja snage po cilindru i smanjenja debljine košuljica, intenzitet kavitacionih razaranja stalno je $\mathrm{u}$ porastu, zbog čega je neophodno proučavanje problema nastajanja kavitacije, njenog negativnog uticaja na rashladne površine, kao i mera zaštite od ove pojave.

$\mathrm{Na}$ osnovu eksperimenata, koji su do sada realizovani na brodskim dizel motorima, može se doći do određenih saznanja: o uzrocima pojave kavitacije, mestima gde se javlja, vrstama nastalih oštećenja na rashladnim površinama, posledicama po pouzdanost rada brodskog dizel motora, o merama zaštite od kavitacije i načinu primene mera zaštite radi produžavanja veka trajanja cilindarskih košuljica i povećanja pouzdanosti rada brodskih dizel motora.

\section{Kavitacija}

Početak nastajanja kavitacije vezan je za veličinu pritiska u rashladnoj tečnosti. Naime, smanjenjem pritiska na vrednost isparavanja tečnosti na određenoj temperaturi, dolazi do pojave stvaranja mehurića, što se smatra početkom nastajanja procesa kavitacije. Početak pojave procesa kavitacije nastaje prekomernim padom pritiska ili lokalnim ubrzanjem struje rashladne tečnosti. Mehurići pare, nošeni strujom tečnosti, dolaskom u polje povišenog pritiska se kondezuju. Ako se kondenzacija završava blizu površine čvrstog tela ili na njoj, dolazi do pojave razaranja materijala tog tela, što se naziva kavitacionom erozijom [2].

Proces isparavanja tečnosti događa se na svim temperaturama pri atmosferskom pritisku, međutim, sa aspekta proučavanja kavitacije interesantno je ključanje na nižim pritiscima i temperaturama, odnosno „hladno ključanje“. Kao rashladno sredstvo brodskih dizel motora najčešće se koristi voda, čija je zavisnost pritiska ključanja od temperature $p=f(t)$ prikazana na slici 1 .

Rashladna tečnost u sebi sadrži određeni procenat nerastvorenih gasova $\left(\mathrm{O}_{2}, \mathrm{~N}_{2}, \mathrm{CO}_{2}\right.$, vazduh i dr. $)$ u obliku mehurića koji predstavljaju klice - centre 


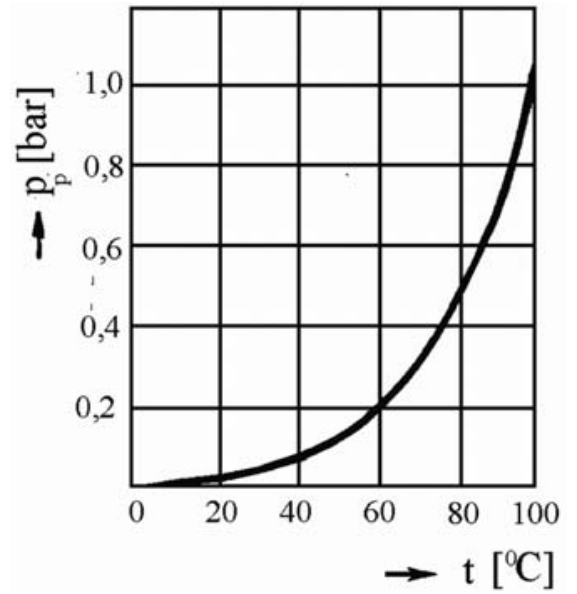

Sl. 1 - Zavisnost temperature ključanja vode od pritiska

kavitacije. Veličina mehurića je različita i zavisi od pritiska tečnosti. Najmanja dimenzija gasnih mehurića je reda veličine $1 \mu \mathrm{m}$, a zavisi od stišljivosti gasova. Mehurići gasa, nošeni strujom tečnosti, dolaze u polje sniženog pritiska koji odgovara temperaturi isparavanja, a difuzijom kroz površinu (opnu) mehurića ustrujava para, zbog čega zapremina mehurića stalno raste. Kada mehurić, nošen strujom, dođe u polje povećanog pritiska dolazi do kondenzacije pare i smanjenja njegove zapremine.

Za analizu dobijenih rezultata, kako teorijskih, tako i eksperimentalnih, pri procesima kavitacije koristi se bezdimenzijski broj k, koji predstavlja odnos sile zbog razlike u pritiscima, prema inercijalnoj sili. Ovaj broj naziva se Ojlerov ili kavitacioni broj, a veoma lako se dobija iz Navije-Stoksove jednačine za pritisak ključanja tečnosti $p_{k}$ :

$$
k=\frac{p_{1}-p_{k}}{\rho \cdot v_{1}^{2}}
$$

gde je:

$p_{1}[P a]$ - pritisak struje rashladne tečnosti, $p_{k}[P a]-$ pritisak ključanja tečnosti, $\rho\left[\frac{\mathrm{kg}}{\mathrm{m}^{3}}\right]$ - gustina rashladne tečnosti, i $v_{1}\left[\frac{m}{s}\right]$ - brzina strujanja rashladne tečnosti.

Zbog prisustva mehurića $u$ tečnosti koja struji, njen protočni presek se smanjuje. Od broja mehurića u struji tečnosti zavisi smanjenje protočnog preseka, kao i promena strujnih karakteristika. Promene strujnih karakteristika mogu ići čak dotle da potpuno zaguše strujni tok.

U procesu kavitacije postoje tri faze: prva faza - stvaranje mehurića, druga faza - rast mehurića, i treća faza - nestajanje mehurića.

Prva faza kavitacije povezana je sa mehanizmom nastajanja mehurića i kaverni zbog prisustva nerastvorenih gasova u tečnosti. Postoje dva modela pomoću kojih je moguće objasniti stvaranje centra kavitacije. Prvi model (slika 2a) odnosi se na stvaranje mehurića na površini tela. Naime, svaka površina je, u manjoj ili većoj meri, hrapava što potiče od tehnolo-

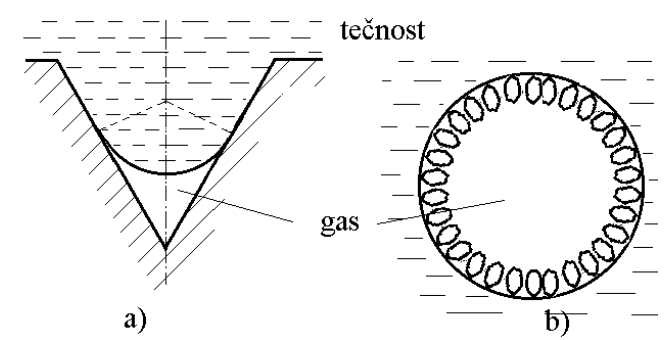

Sl. 2 - Proces stvaranja mehurića na površini tela 
škog procesa obrade površine, ali i od uslova eksploatacije. U tim mikroneravninama nalaze se ,zarobljeni“" mehurići nerastvorenih gasova koji u uslovima delovanja kritičnog pritiska u okolnoj tečnosti predstavljaju centre isparavanja tečnosti.

Drugi model (slika 2b), takođe, zasniva se na prisustvu nerastvorenih gasova u tečnosti. Mehurići nerastvorenih gasova nošeni strujom tečnosti dolaze u zonu gde pritisak dostiže vrednost isparavanja, pri čemu im se povećava zapremina.

Osim ova dva modela formiranja centara isparavanja tečnosti, treba naglasiti da parni mehurić može nastati i u centrima vrtloga. Na slici 3 prikazan je proces stvaranja mehurića na čvrstoj površini i ,životni put" parnog mehurića pri opstrujavanju tela. U odgovarajućem preseku na telu (slika 3a) pritisak dostiže vrednost $p_{k}$, kada mehuriću nastalom od nerastvorenih gasova, koji se nalazi na zidu, raste zapremina zbog isparavanja tečnosti.

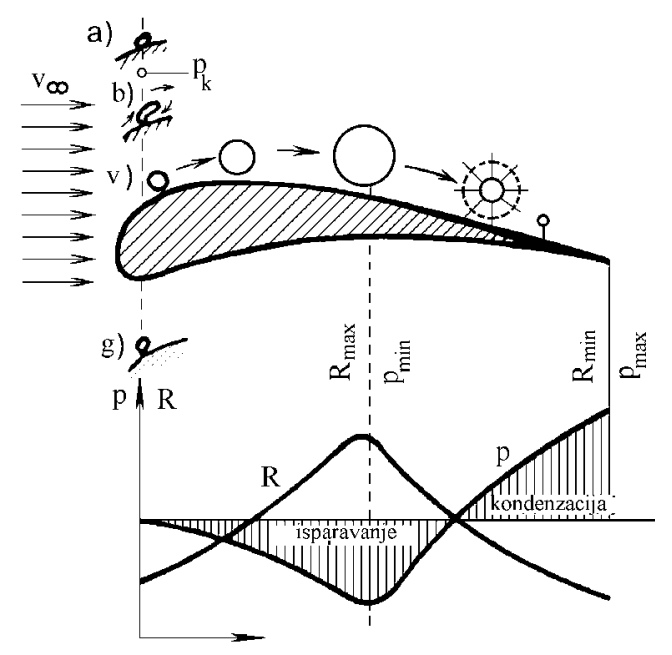

Sl. 3 - Proces stvaranja mehurića na površini tela $i$, ,životni put" parnog mehurića pri opstrujavanju tela
Dejstvom hidrodinamičkih sila nastali mehurić raste (slika $3 b$ ), deformiše se i izdužuje u smeru strujanja. U trenutku kada hidrodinamičke sile nadvladaju površinske sile prijanjanja mehurića za čvstu površinu, on se otkida od te površine (slika 3v), a na tom mestu (slika 3g) započinje ciklus stvaranja novog. Taj proces stvaranja mehurića nastavlja se sve dok postoje uslovi za održavanje kritičnog pritiska $p_{k}$.

Otkidanjem parnog mehurića sa zida započinje druga faza njegovog ,života“ rast mehurića. Stvoreni mehurići u tečnosti su različitih veličina i oblika. Međutim, pri analizi se pretpostavlja da mehurići imaju oblik sfere koja je ispunjena parom ili parom i gasom. Otkinuti mehurić nosi struja tečnosti u smeru strujanja, tako da na mestima gde se povećava brzina pritisak pada, mehurić raste i obrnuto.

Od trenutka kada se u tečnosti postigne pritisak $p>p_{k}$, uslovi za opstanak parne faze prestaju i nastaje kondenzacija mehurića - treća faza. Kako se kondenzacija obavlja trenutno, obično se smatra da je mehurić iščezao ili da je doživeo kolaps. Pri kondenzaciji mehurića zapremina parne faze se trenutno smanjuje, a u nju velikom brzinom ustrujava tečnost. Usled toga, na mestima kolapsa mehurića nastaju lokalni hidro udari propraćeni naglim lokalnim porastom pritiska. Ako se kondenzacija mehurića završava na čvrstoj površini ili blizu nje, tada je ta površina izložena dejstvu velike sile (reda veličine 1000 do $1500 \mathrm{MPa}$ ) na maloj površini. Kod dugotrajnog procesa kondenzacije mehurića na čvrstoj površini ona će biti oštećena, a taj proces naziva se kavitacionom erozijom. Svi mehurići koji se kondenzuju ne učestvuju u ra- 
zaranju površine, već samo oni koji iščezavaju na njoj ili blizu nje.

Proces kavitacione erozije propraćen je površinskim razaranjem materijala, pa samim tim i gubitkom njegove mase. Svi materijali, bez obzira na kvalitet $\mathrm{i}$ mehanička svojstva, podložni su kavitacionoj eroziji. Pri razvijenoj kavitaciji samo je pitanje vremena kada će nastupiti razaranje površinskog sloja. Ispitivanje procesa kavitacije obavlja se u laboratorijskim uslovima, jer ispitivanje na objektima u stvarnim uslovima eksploatacije nije preporučljivo, zbog narušavanja radnog procesa i promene karakteristika, kao i zbog toga što je ova pojava u eksploataciji nepoželjna. U laboratorijskim uslovima brže se dolazi do podataka o kavitacionoj eroziji.

$\mathrm{Na}$ metalnim površinama stalno je prisutna i korozija, pa je u normalnim uslovima eksploatacije na mestima sa procesom kavitacije stalno prisutan i korozivno-erozivni proces. Eksperimentima u laboratorijskim uslovima dobijeni su podaci o gubitku mase (tabela) različitih vrsta materijala u uslovima kavitacione erozije.

Gubitak mase nekih materijala u uslovima kavitacione erozije

\begin{tabular}{|c|c|c|c|}
\hline Materijal & Način obrade & Sastav & \begin{tabular}{|} 
Gubitak \\
mase uzorka \\
posle $2 \mathrm{~h}$ \\
ispitivanja \\
$\Delta \mathrm{m}[\mathrm{mg}]$
\end{tabular} \\
\hline \multirow{2}{*}{ Bronza } & toplo valjana & $\begin{array}{c}\mathrm{Cu} 83 \% ; \mathrm{Al} \\
10,3 \% ; \mathrm{Fe} 5,8 \%\end{array}$ & 3,2 \\
\hline & livena & $\begin{array}{c}\mathrm{Cu} 83,1 \% ; \mathrm{Al} \\
12,4 \% ; \mathrm{Fe} 4,1 \% \\
\end{array}$ & 5,8 \\
\hline \multirow{4}{*}{ Čelik } & $\begin{array}{l}\text { valjan, otporan } \\
\text { na koroziju }\end{array}$ & Cr 26\%; Ni 13\% & 8,0 \\
\hline & $\begin{array}{l}\text { valjan, otpušten, } \\
\text { otporan na koro- } \\
\text { ziju }\end{array}$ & Cr $12 \%$ & 9,0 \\
\hline & $\begin{array}{l}\text { liven, otporan na } \\
\text { koroziju }\end{array}$ & Cr 18\%; Ni 8\% & 13 \\
\hline & & Cr $12 \%$ & 20 \\
\hline \multicolumn{3}{|c|}{ Aluminijum } & 124 \\
\hline \multirow{2}{*}{\multicolumn{3}{|c|}{ Kovano gvožđe }} & 156 \\
\hline & & & 224 \\
\hline
\end{tabular}

\section{Pojava kavitacije u brodskim dizel motorima}

Oštećenja površina cilindarskih košuljica i blokova cilindara hlađenih vodom posledica su istovremenog dejstva mehaničkih, hemijskih, toplotnih i elektrohemijskih procesa. Pri analizi oštećenja najpre se smatralo da su ona posledica korozije zbog prisustva kiseonika. Međutim, kasnijim eksperimentima došlo se do saznanja da oštećenja rashladnih površina direktno zavise od kavitacije. Glavni uzrok kavitacije i kavitacionih oštećenja je promenljivi pritisak u rashladnoj tečnosti, izazvan oscilacijama cilindarskih košuljica, što je zaključeno na osnovu direktne zavisnosti između pojave kavitacije i procesa koji se odvijaju u cilindru dizel motora, kao i na osnovu identičnosti karaktera i oblika oštećenja na rashladnoj površini cilindarske košuljice brodskih dizel motora i brodskih propelera, usisnih delova hidrauličnih mašina i dr.

$\mathrm{Na}$ spoljnoj površini cilindarskih košuljica, koje se hlade vodom, dolazi do oštećenja nastalih procesom kavitacije. Kavitaciona oštećenja spoljnih površina košuljica dizel motora nastaju zbog pulziranja vode usled dejstva normalne sile koja nastaje pri udaru klipa o zid cilindarske košuljice. Udarni impuls izaziva lokalne elastične deformacije u obliku radijalnih i uzdužnih oscilacija cilindarske košuljice koje dovode do pobuđivanja zvučnih i ultrazvučnih oscilacija u prstenastom sloju vode oko cilindarske košuljice, odnosno izaziva njeno pulziranje.

Procesi pulziranja vode za hlađenje uz oscilatorne površine utiču na stvaranje kavitacionih mehurića. Pri nestajanju 
mehurića stvara se prazan prostor na površini cilindarske košuljice, a voda velikom brzinom nadire (naleće) u taj prostor i udara u površinu cilindarske košuljice. Pritisak vode $\mathrm{u}$ tim slučajevima kreće se u granicama od 1000 do 1500 $\mathrm{MPa}$, a čvrstoća sivog liva (od koga je košuljica izrađena) iznosi od 200 do 400 $\mathrm{MPa}$. Tada najveća opterećenja na mikropovršini, na kojoj deluje navedeni pritisak, prelaze granicu tečenja metala, što dovodi do skidanja (erozije) njegovih delova. Zbog udaranja klipa o cilindarsku košuljicu nastaju oštećenja i mikropukotine i na površini sa strane hlađenja. Zbog pojave ponovnih hidrauličnih udara čestice sa tih površina se otkidaju, a oko tog mesta stvara se mreža pukotina koje se s vremenom produbljuju. Iz sivog liva najpre se oslobađaju grafitni sastojci koji imaju zanemarljivo malu čvrstoću u odnosu na metal. Kod čvršćih i tvrđih konstrukcionih materijala ovaj proces razaranja teče relativno sporo. Paralelno sa mehaničkim prisutna su i hemijska, toplotna i elektrohemijska oštećenja rashladnih površina. Pri naglom nadiranju mehurića visokog pritiska u mikroprostore tečnosti dolazi do naglog povećanja temperature. U tom slučaju, kada mehurić dođe u dodir sa površinom cilindarske košuljice $\mathrm{i}$ ako je temperatura u tom mikroprostoru veća od temperature topljenja materijala košuljice, materijal se na toj površini topi. Viša temperatura pojačava elektrohemijske procese, a njihova uloga pri kavitaciji koja se razvija na površini cilindarske košuljice je poznata. Naime, udarci klipa o košuljicu izazivaju deformacije i povećavaju opterećenje materijala na maloj površini. Na tim mestima nastaju anodni sektori, koji sa vodom za hlađenje (elektrolitom) i osnovnom površinom cilindarske košuljice (katodom) formiraju galvanski par. U sistemima za hlađenje dizel motora osim kavitacije javljaju se i procesi korozije koji potpomažu oštećenja. Pod uticajem kavitacije razaranje materijala je stalno, a posebno je velikog intenziteta kada se stalno ponavljaju kavitaciono-korozivni procesi.

Procesi kavitacije ispituju se pomoću mikrofotografija i metodom difrakcije rendgenskih zraka. U oba slučaja kod kavitacionih oštećenja primećuju se i plastične deformacije. Ispitivanja uzoraka materijala različitog hemijskog sastava pokazala su da su oštećenja nastala kavitacijom jednaka. Osim toga, vršena su ispitivanja uzoraka od nikla u vodi i u tečnom metil-benzolu, bez prisustva vazduha i dodira sa helijumom. U obe tečnosti kavitacija je izazvala plastične deformacije jednakog oblika i veličina. Eksperimenti izvršeni sa uzorcima od nerđajućeg čelika, zlata, platine, plastične mase, gume i drugih neoksidirajućih materijala dali su iste rezultate. Svi ovi materijali imali su oštećenja nastala uticajem kavitacije. To znači da nema materijala koji je apsolutno otporan na uticaj kavitacione erozije.

Mehanizam razaranja čvrstih tela, $u$ prvom redu, zavisi od uzroka pojava kavitacionog razaranja. Uzročni faktori, uglavnom, zavise od prepreka u struji tečnosti (u rashladnom prostoru dizel motora) i zatvorenih (zarobljenih) kavitacionih mehurića. Međutim, ukoliko se primene mere za smanjenje kaverni, tada se u principu uvek smanjuju i kavitaciona oštećenja opstrujavanih površina cilindarskih košuljica i blokova cilindara. 
Osim oštećenja nastalih od kavitacije na košuljicama i blokovima cilindara, kod brodskih dizel motora primećena su oštećenja izazvana kavitacijom i na ležajima kolenastog vratila, elementima sistema za ubrizgavanje goriva (pumpa za gorivo, ubrizgač goriva) [1], ventilima motora, pumpama za rashladnu vodu i dr. U sistemu za hlađenje klipa kavitacija se javlja u teleskopskim cevima. Kolenasto vratilo se ne obrće ravnomerno u ležajima, već izvodi složeno kretanje u zavisnosti od sila koje na njega deluju. Ako se zbog pomeranja zazor između vratila $i$ ležišta naglo poveća, nastaju mehurići u ulju za podmazivanje, koji implodiraju kada se vratilo približava ležišnoj šolji, što dovodi do pojave kavitacione erozije.

\section{Zavisnost kavitacionih razaranja od temperature i pritiska rashladne tečnosti}

Laboratorijska ispitivanja pojave kavitacije obavljaju se različitim metodama na različitim uređajima. $U$ ovom radu korišćeni su podaci dobijeni merenjem na magnetostrikcionom oscilatoru. Ovi podaci dobijeni su pri ispitivanju modela u različitim sredinama rashladne tečnosti sa konstantnim veličinama hidrostatskog pritiska, konstantnim zazorima $(20 \mathrm{~mm})$ između aktivnih i pasivnih modela $\mathrm{i} u$ intervalu od 30 do $90^{\circ} \mathrm{C}$.

Pri ispitivanju su korišćene sledeće rashladne tečnosti: voda iz vodovoda, voda iz vodovoda sa $0,5 \%$ sadržajem aditiva i posebno pripremljena voda.

\section{Voda iz vodovoda}

Na slici 4 prikazana je zavisnost kavitacionih razaranja od temperature vode za četiri konstantne vrednosti pritisaka, pri čemu se razaranje odnosi na ukupnu rashladnu površinu motora. Uočava se da veličina kavitacionih razaranja zavisi od količine kavitacionih mehurića u vodi.

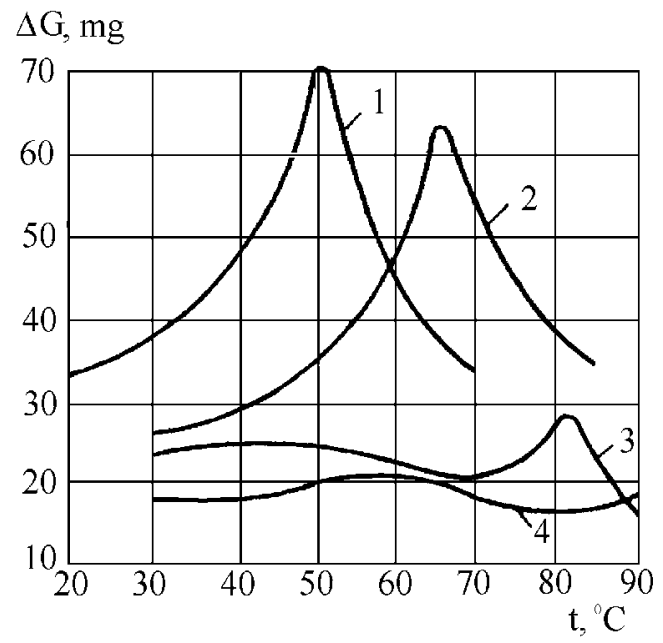

Sl. 4 - Zavisnost kavitacionih razaranja od temperature i pritiska vode:

1. $p=0,05 \mathrm{MPa}$; 2. $p=0,15 \mathrm{MPa}$;

3. $p=0,25 \mathrm{MPa}$; 4. $p=0,29 \mathrm{MPa}$

Pošto se sa povećanjem temperature vode smanjuje zasićenje gasom i slabe amortizaciona svojstva gasova rastvorenih u vodi, veličina razaranja modela, u prvom trenutku naznačenih pritisaka, raste i dostiže maksimalnu vrednost na temperaturama od $50^{\circ}, 65^{\circ} \mathrm{i}$ $80^{\circ} \mathrm{C}$. Daljim porastom temperature vode dolazi do ubrzanog preobražaja unutar kavitacionih mehurića koji, zahvaljujući tome, ponovo dobijaju amortizaciona svojstva. $\mathrm{Na}$ osnovu rezultata $\mathrm{i}$ karaktera prikazanih grafova vidi se da se veličina kavitacionih razaranja smanjuje sa povećanjem temperature i pritiska, pri čemu se maksimalne vrednosti razaranja dostižu na višim temperaturama. 
Prema tome, pri pritisku $\mathrm{p}=0,05$ $\mathrm{MPa}$ (kriva 1) maksimalna razaranja $(\Delta G \approx 70 \mathrm{mg})$ su u zoni temperature od $50^{\circ} \mathrm{C}$, pri pritisku $\mathrm{p}=0,15 \mathrm{MPa}$ (kriva 2 , $\Delta G \approx 64 \mathrm{mg}$ ) na temperaturi od $65^{\circ} \mathrm{C}$, pri pritisku $\mathrm{p}=0,25 \mathrm{MPa}$ (kriva 3, $\Delta G \approx 28 \mathrm{mg}$ ) na temperaturi od $80^{\circ} \mathrm{C}$, dok pri pritisku $\mathrm{p}=0,29 \mathrm{MPa}$ (kriva 4, $\Delta G \approx 22 \mathrm{mg}$ ) na temperaturi od $90^{\circ} \mathrm{C}$ maksimalnih razaranja gotovo da i nema. Ovakvi rezultati merenja objašnjavaju se kasnijim početkom nastajanja pare pri povišenim pritiscima vode $\mathrm{u}$ sistemu. Analizom apsolutnih veličina razaranja modela (gubitka mase) po krivama 1 do 4, uočava se da sa povećanjem pritiska iznad vrednosti $\mathrm{p}=0,25 \mathrm{MPa}$ (krive 3 i 4) veličina kavitacionih razaranja postaje stabilna $\mathrm{u}$ intervalu temperatura od $30^{\circ} \mathrm{C}$ do $90^{\circ} \mathrm{C}$ i manja je za 2,5 do 3,5 puta $\mathrm{u}$ odnosu na vrednosti za pritiske prikazane krivama 1 i 2.

\section{Voda iz vodovoda sa aditivima}

Za ovu analizu korišćena je voda iz vodovoda kojoj je dodata određena količina aditiva $(0,5 \%$ Schell Dromus oil $\mathrm{B} \mathrm{u}$ odnosu na ukupnu masu vode u sistemu). Ispitivanja su vršena pri konstantnim pritiscima od 0,15 i $0,29 \mathrm{MPa}$ na različitim temperaturama, a rezultati su prikazani na slici 5 . Na dijagramu su prikazane i vrednosti kavitacionih oštećenja za vodu iz vodovoda (bez aditiva) pri istim pritiscima, što omogućava upoređivanje rezultata i donošenje određenih zaključaka.

Koncentracija aditiva sa $0,5 \%$ uzeta je na osnovu ranijih ispitivanja čiji su rezultati pokazali da je to optimalna količina. Kod manjih koncentracija aditiva veći su gubici mase nastali kavitacijom, dok se kod većih koncentracija ti gubici neznatno smanjuju. Kod nekih vrsta aditiva sa koncentracijom $>0,5 \%$ povećavaju se oštećenja i gubici mase usled pojave kavitacije.

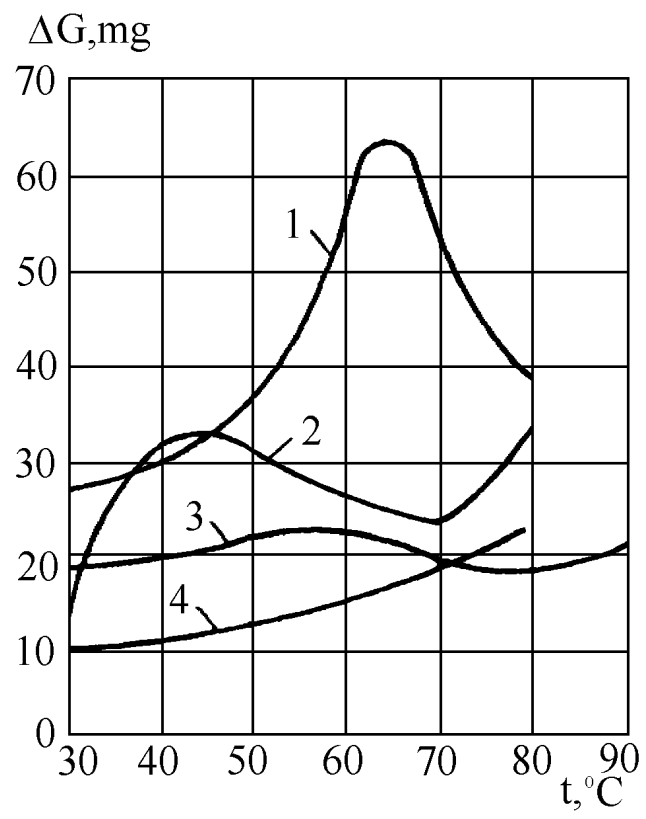

Sl. 5 - Zavisnost kavitacionih razaranja od temperature i pritiska vode bez $i$ sa aditivom: 1. $p=0,15 \mathrm{MPa}$ (voda iz vodovoda); 2. $p=0,15 \mathrm{MPa}$ (voda sa aditivima); 3. $p=0,29 \mathrm{MPa}$ (voda iz vodovoda); 4. $p=0,29 \mathrm{MPa}$ (voda sa aditivima)

Sa slike 5 vidi se da pri pritisku od $0,15 \mathrm{MPa}$ kavitaciono razaranje u vodi bez aditiva (kriva 1 ) ima najveće vrednosti na temperaturi od oko $65^{\circ} \mathrm{C}$. U vodi sa aditivima (kriva 2) na istom pritisku kavitaciono razaranje ima relativno najveće oscilovanje $\mathrm{u}$ intervalu temperature od $35^{\circ} \mathrm{C}$ do $80^{\circ} \mathrm{C}$, a po apsolutnoj vrednosti znatno manji gubitak mase u odnosu na vodu bez aditiva.

Povećanjem hidrostatskog pritiska do vrednosti od 0,29 MPa apsolutna vred- 
nost razaranja je dva do tri puta manja (kriva 4). Znači da sa povećanjem temperature veličina razaranja u vodi sa aditivima postepeno raste. $U$ intervalu temperatura od $30^{\circ}$ do $72^{\circ} \mathrm{C}$ gubitak mase zbog kavitacije je za 1,5 do 2 puta manji nego kod modela ispitivanog $\mathrm{u}$ vodi bez aditiva (kriva 3). Međutim, pri temperaturama višim od $72^{\circ} \mathrm{C}$ gubitak mase zbog kavitacije $\mathrm{u}$ vodi sa aditivima mnogo je veći nego $\mathrm{u}$ vodi bez aditiva. To se može objasniti smanjenjem adhezionih osobina aditiva sa povećanjem temperature.

\section{Posebno pripremljena voda}

Posebno pripremljena voda (voda visoke čistoće) dobija se neutralizacijom, odnosno odstranjivanjem soli i kiseonika iz nje. Time se voda praktično prevodi $\mathrm{u}$ dielektrik (električni otpor iznosi do 10 $\Omega \mathrm{cm}$ ) i povećava joj se površinski napon (u poređenju sa destilovanom vodom skoro dva puta). To znači da se upotrebom ovakve vode u rashladnom sistemu dizel motora isključuje proces elektrohemijske korozije, dok se razaranja nastala kavitacionom erozijom smanjuju.

Na slici 6 prikazana je zavisnost veličine kavitacionih razaranja od temperature $u$ vodi visoke čistoće (krive 1 i 4) pri konstantnim hidrostatskim pritiscima koji imaju vrednosti 0,15 i 0,29 MPa.

$\mathrm{Na}$ slici su prikazane i dobijene vrednosti gubitaka mase pri istim hidrostatskim pritiscima modela $u$ vodi iz vodovoda (krive 2 i 3) radi upoređenja sa rezultatima ispitivanja modela $\mathrm{u}$ vodi visoke čistoće. Uočava se da se maksimalni gubitak mase modela u vodi visoke čistoće (krive 1 i 4 ) dešava nezavisno od pritiska na nižim temperaturama od oko
$\Delta \mathrm{G}, \mathrm{mg}$

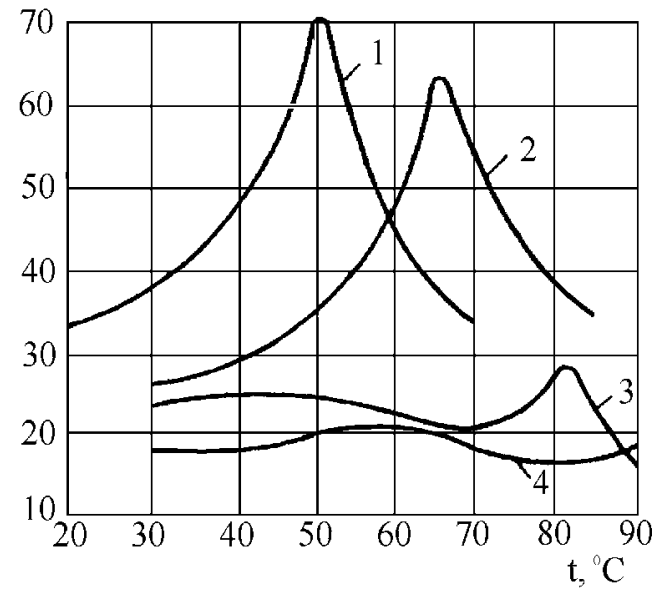

Sl. 6 -Zavisnost kavitacionih razaranja od temperature vode visoke čistoće pri konstantnim hidrostatskim pritiscima:

1. $p=0,15 \mathrm{MPa}$ (voda visoke čistoće);

2. $p=0,15 \mathrm{MPa}$ (voda iz vodovoda); 3. $p=0,29 \mathrm{MPa}$ (voda iz vodovoda); 4. $p=0,29 \mathrm{MPa}$ (voda visoke čistoće)

$50^{\circ} \mathrm{C}$. Apsolutna vrednost razaranja u toj sredini pri pritisku od 0,29 MPa (kriva 4) gotovo je tri puta manja u odnosu na pritisak 0,15 MPa (kriva 1) tj. skoro šest puta $\mathrm{u}$ odnosu na vodu iz vodovoda (kriva 2) pri temperaturi od $65^{\circ} \mathrm{C}$. Daljim porastom temperature veličina razaranja $u$ oba slučaja (voda visoke čistoće) smanjuje se, s tim da pri pritisku od 0,15 MPa naglo opada, a na temperaturi od $70^{\circ} \mathrm{C}$ i višoj, apsolutna veličina razaranja postaje praktično jednaka, nezavisno od veličine hidrostatskog pritiska.

Upoređenjem karaktera razaranja $\mathrm{u}$ posmatranoj sredini (krive 1 i 4) sa karakterom razaranja u vodi iz vodovoda (krive 2 i 3) može se primetiti da je na pritisku od $0,15 \mathrm{MPa}$ i temperaturi od oko $50^{\circ} \mathrm{C}$ razaranje u vodi visoke čistoće većeg intenziteta. Dalje povećanje temperature dovodi do znatnog razaranja $u$ 
neutralizovanoj vodi. Pri pritisku od 0,29 $\mathrm{MPa}$, u svim intervalima temperatura, veličina razaranja modela je $u$ neutralizovanoj vodi donekle manja u odnosu na vodu iz vodovoda.

Prema tome, u neutralizovanoj vodi u poređenju sa vodom iz vodovoda znatno su manje vrednosti gubitka mase modela nastalih kavitacionom erozijom kod niskih pritisaka temperaturama $50^{\circ} \mathrm{C}$ i višim. Pri povećanju hidrostatskog pritiska (0,25 do 0,29 MPa i višim) rashladna tečnost manje utiče na kavitaciono razaranje, pa su njihove apsolutne vrednosti prilično niske $u$ obe sredine.

\section{Zaključak}

Savremeni visokotermički opterećeni brodski dizel motori hlade se na više načina, a najčešće vodom, pri čemu se javljaju određeni problemi, jer dolazi do oštećenja rashladnih površina nastalih uticajem kavitacione erozije, odnosno gubitkom mase rashladnih površina.

Pojava kavitacije na rashladnim površinama brodskih dizel motora povezana je sa padom pritiska do vrednosti ključanja i isparavanja rashladne tečnosti na nižim temperaturama. Tom prilikom nastaju parni mehurići, pri čemu im se povećava zapremina, odvajaju se sa rashladnih površina i stvaraju slobodan prostor određene zapremine. U taj prostor naglo ustrujava okolna tečnost pod veoma visokim pritiskom, i otkida čestice materijala rashladne površine (proces kavitacione erozije), pri čemu dolazi do oštećenja tih površina.

$\mathrm{Za}$ proces nastajanja kavitacije od posebnog je značaja uticaj koncentracije aditiva u rashladnoj vodi kao i pritisaka $i$ temperature u sistemu hlađenja. Kod brodskih dizel motora do maksimalnog gubitka mase cilindarskih košuljica, nastalog procesom kavitacije, dolazi na režimu rada pri temperaturi rashladne vode oko $50^{\circ} \mathrm{C}$. Povećanjem pritiska rashladne vode, upotrebom aditiva određene koncentracije i materijala veće čvrstoće, smanjuje se uticaj kavitacione erozije na rashladnim površinama cilindarskih košuljica. Osim uticaja kavitacione erozije, na dužinu veka upotrebe u eksploataciji cilindarskih košuljica bitno utiču mehanička oštećenja, hemijski i elektrohemijski procesi, proces korozije, toplota $\mathrm{i}$ drugi činioci. Svi materijali, bez obzira na kvalitet i mehanička svojstva, podložni su kavitacionoj eroziji.

Literatura:

[1] Ivošević, S.: Kavitacija u sistemu za ubrizgavanje sporohodnih dizel motora, doktorska disertacija, Mašinski fakultet, Beograd, 1972.

[2] Cantrak, S.; Crnojević, C.: Hidraulika, teorija, problemi, zadaci, Građevinska knjiga, Beograd, 1990.

[3] Čantrak, S.; Crnojević, C.; Radojević, Z.; Jovanović, P.: Hidraulika, kavitacija, elektrohidraulika, OMO, Beograd, 1987.

[4] Рождественский, В. В.: Кавитация, Судостроение, Леннинград, 1977.

[5] Пимощенко, А. П.: Защита судовых дизелей от кавитационных разрушений, Судостроение, Ленинград, 1983.

[6] Đorđević, V.: Pregled metoda za laboratorijska ispitivanja kavitacione erozije, Tehnika, Mašinstvo, Beograd, 1973.

[7] Nikolić, R.: Istraživanje problema kavitacije brodskih dizel motora, magistarski rad, Mašinski fakultet, Beograd, 1999. 


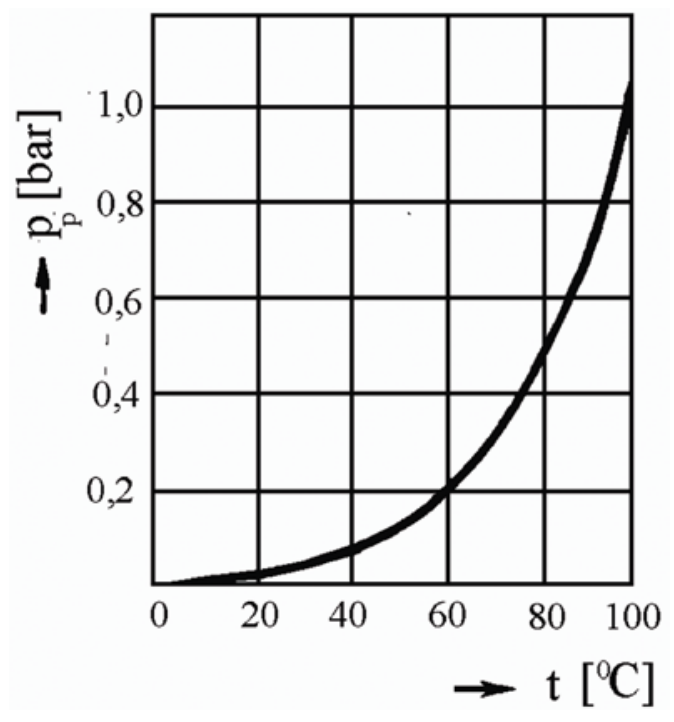

Sl. 1 - Zavisnost temperature ključanja vode od pritiska 


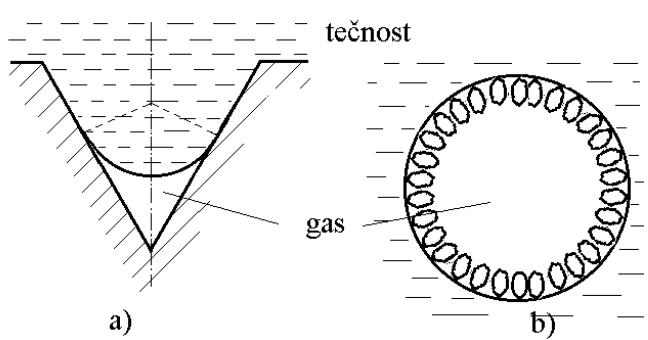

Sl. 2 - Proces stvaranja mehurića na površini tela

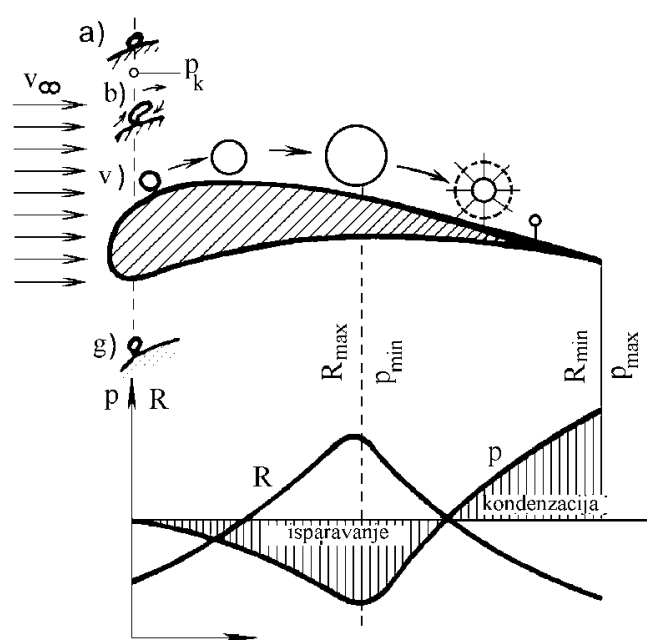

Sl. 3 - Proces stvaranja mehurića na površini tela $i$,„̌̌ivotni put“ parnog mehurića pri opstrujavanju tela 
1. $p=0,05 \mathrm{MPa}$;2. $p=0,15 \mathrm{MPa}$

3. $p=0,25 \mathrm{MPa}$; 4. $p=0,29 \mathrm{MPa}$
1. $p=0,15 \mathrm{MPa}$ (voda iz vodovoda);

2. $p=0,15 \mathrm{MPa}$ (voda sa aditivima);

3. $p=0,29 \mathrm{MPa}$ (voda iz vodovoda);

4. $p=0,29 \mathrm{MPa}$ (voda sa aditivima) onih razaranja od temperature $i$ pritiska vode

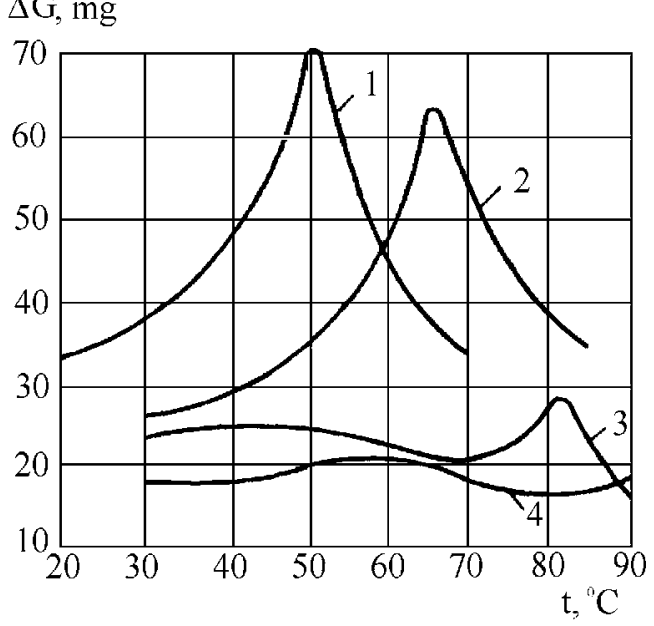

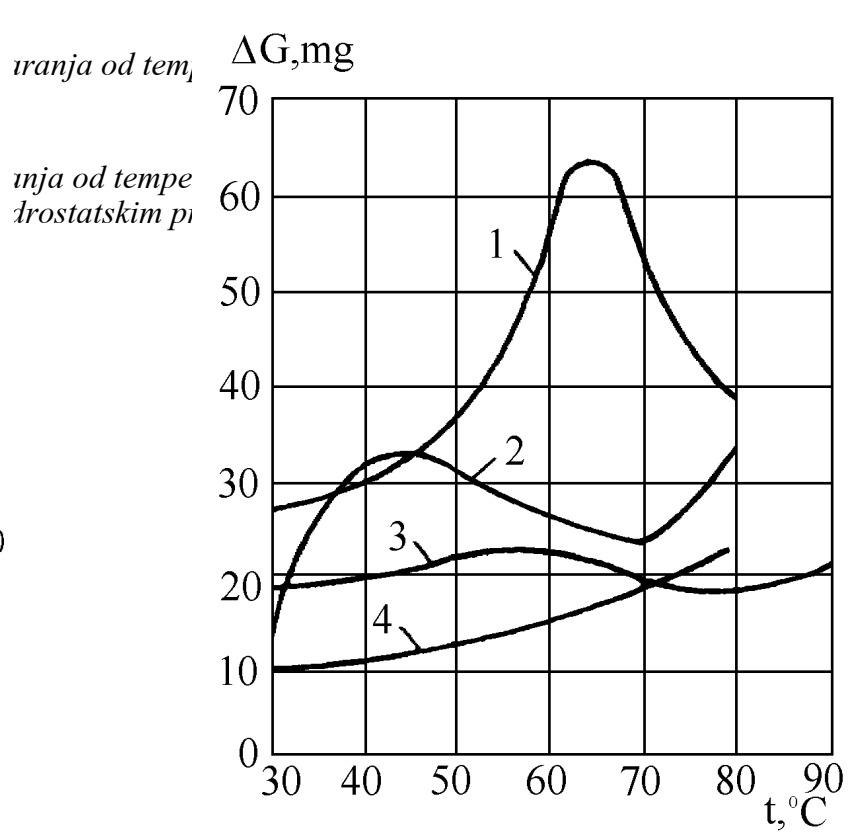

1. $p=0,15 \mathrm{MPa}$ (voda visoke čistoće);

2. $p=0,15 \mathrm{MPa}$ (voda iz vodovoda);

3. $p=0,29 \mathrm{MPa}$ (voda iz vodovoda)

4. $p=0,29 \mathrm{MPa}$ (voda visoke čistoće)

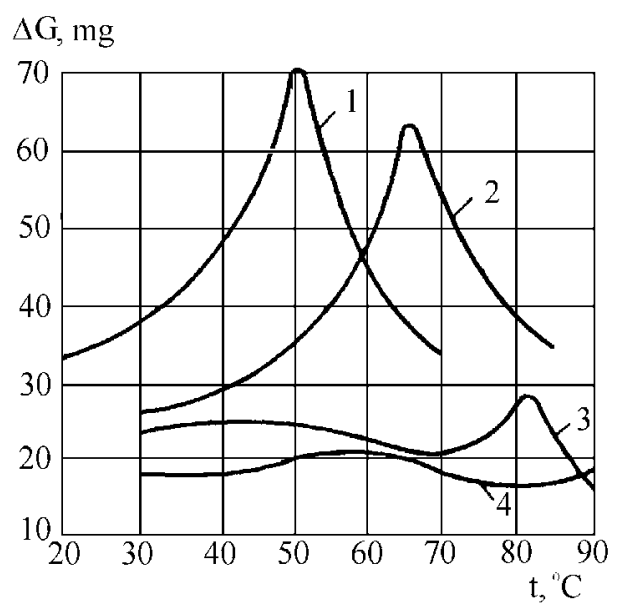

